DedikasiMU (Journal of Community Service)

Volume 3, Nomor 1, Maret 2021

\title{
THE IMPLEMENTATION OF GAME TO INCREASE COURAGE CHILDREN TO SPEAKING ENGLISH IN DAHANREJO VILLAGE GRESIK
}

\author{
${ }^{1}$ Risca Hidayanti Qurani, ${ }^{2}$ Safira Dewi Kurnia, ${ }^{3}$ Henny Dwi Bhakti, ${ }^{4}$ Andi Rahmad Rahim, \\ ${ }^{5}$ Sukaris, ${ }^{6}$ Nur Fauziyah \\ 1,2English Department of Muhammadiyah University \\ ${ }^{3}$ Informatic Engineer Departement University of Muhammadiyah Gresik \\ ${ }^{4}$ Dosen Program Studi Budidaya Perikanan, Universitas Muhammadiyah Gresik \\ ${ }^{5}$ Dosen Program Studi Manajemen, Universitas Muhammadiyah Gresik \\ ${ }^{6}$ Dosen Program Studi Pendidikan Matematika, Universitas Muhammadiyah Gresik \\ Email : risca.qurani@yahoo.com
}

\begin{abstract}
This study aims to increase courage children to speaking English using implementation of game in Dahanrejo village, Kebomas, Gresik. The author as tutors and teachers for children in Dahanrejo village in this research. The problems refer to in Dahanrejo village, many children are afraid to speak English because there are no motivation to increase knowledge related studying English, therefore they have lack vocabulary and also teachers can't explore the other media to teaching English in the classroom. The results of the action research given by the authors are the application of the media can improve the English language skills especially speaking of students and be able to provide variations in indoor learning that are not only fixed on the Package Books and Students Worksheets (LKS). Not only that, but the authors also found that the media was able to change the mood of students who did teaching through the media and were more interested in English.
\end{abstract}

Keywords: Speaking, Motivation, Games. 


\section{DedikasiMU (Journal of Community Service)}

Volume 3, Nomor 1, Maret 2021

\section{INTRODUCTION}

\section{A. Background}

Learning English require not only producing the language correctly, but also using it for specific purposes. When people use language, they characteristically do three things : they say something, they indicate how they intend the hearer to take what they said, and they have definite effects on the hearer results. In this condition, it can be utterance that language means something spoken. Every one usually speak or share their opinion with the other person by using it. Students learning language is considered to be successful if they can communicate effectively in their second language. Speaking is a kind of bridge for students between classroom and the world. The teacher must give students practice with speaking activities to connect them with world outside. Considering how important speaking skill in learning English, Renandya (1999, p.230 in Hadi, 2011, p.2) in this case remind English teachers by saying : Speaking in one of the central elements of communication. In EFL teaching, it is an aspect that needs special attention and instruction. In order to provide effective attention, it is necessary for a teacher of EFL to carefully examine the factors, condition and components that underlie speaking effectiveness.

Even though it is not easy to take control speaking skill, there are many problems in learning speaking skill: (1) the limited opportunities for the students to speak in front of the others, (2) the lack of variation of teaching techniques used by the teacher, (3) the teaching strategy application was monotonous that made them bored and disinterested in studying English (Buzanni, 2008, n.p). In view of the these problems, increasing courage students speaking skill are part of teacher's job. Teacher is supposed to have right teaching techniques to provide students, with appropriate teaching materials and to make positive classroom environment. Thus, students will have an opportunity to use English among themselves. One of the techniques that the teacher can apply in teaching speaking is game, because it is one of potential activity that gives students feeling freedom to express themselves (Dwiyanti, 2009, p.3). 


\section{DedikasiMU (Journal of Community Service)}

Volume 3, Nomor 1, Maret 2021

There are some reason why games can increase courage students speaking proficiency. First, games helps teachers to make context in which the language is useful. Students want to join and order to do so they must understand what others say or write, and they must speak and write in order to express their opinion. Second, enjoyment of games is not restricted by age. According to Chen (2000), games make the learners more willing to ask questions and think creatively about how to use English to achieve the goal. They are thus a natural self-expression for both the young and old. They have the advantage to attention in focusing, providing a self motivating environment for the students with their active participation. The advantages of games in the classroom create students have great willingness to practice speaking skill. Su Kim describe as follows : Games are welcome break from the usual routine of the language class, they are motivating and challenging, games provide language practice in the various skill speaking, writing, listening and reading... They create a meaningful context for the language use (1995:35)

Speaking English is one of the scourges for students in Dahanrejo village because most of them doesn't courage to use English among themselves. The English teacher in Dahanrejo also assumption that children in this village need more attention to the vocabulary and pronunciation, and some factor from teacher is also still less skilled in the field of English. Therefore, (Alqahtani, 2015) Teaching vocabulary is one of the most discussed parts of teaching. The teacher must prepare and find the appropriate level of instruction, which will be implemented for students.

There are many advantages of games can intercept the speaking problems. The competition of games give students a natural opportunity to work together and communicate using English with their friends, especially by integrating playing and learning, students practice the learned linguistic knowledge in an useful context. However, based on our experience in Dahanrejo village, the use of guessing game to increase courage speaking skill children. 


\section{DedikasiMU (Journal of Community Service)}

Volume 3, Nomor 1, Maret 2021

\section{B. Significance of the Research}

The authors hope so much this study will yield beneficial results that can be contributed to the English teachers who teach English subject especially in Indonesia or even all over the world as their materials reference. The authors hope to help the English teachers with their problems in teaching speaking in the class. The authors also do hope that this study will help the English learners to master English language especially in speaking component and increase the students' academic achievement.

Especially in Dahanrejo village, authors hope that all children can increase speaking skill among themselves and also teachers can explore the other media to teaching English in the classroom. Therefore, students can connect with world outside because speaking is bridge for students between classroom and the world.

\section{IMPLEMENTATION METHOD}

The method used in this research is action research Kemmis as quoted by Hopkins (1993:44) gives the definition of action research as follows :

Action research is a form of self-reflective inquiry undertaken by participators in a social situation (including education) in order to improve the rationality and justice of (a) their own social or educational practice, (b) their understanding of these practices and $(c)$ the situation in which practices are carried out. 


\section{DedikasiMU (Journal of Community Service)}

Volume 3, Nomor 1, Maret 2021

The spiral model of action research can be illustrated as follow

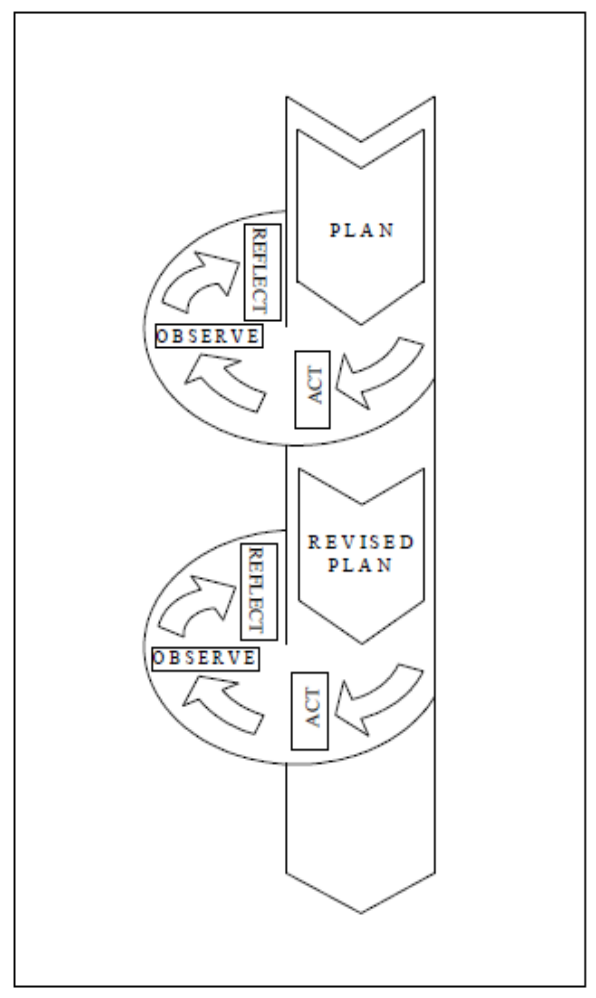

Figure 1. The model of action research by Kemmis and Mc. Taggart

For more deeper understanding about the procedure of this action research, detail explanation are as follows :

\section{Identifying the problem}

The author as tutors and teachers for children in Dahanrejo village in this research identify the problem. The problems refer to in Dahanrejo village, many children are afraid to speak English because there are no motivation to increase knowledge related studying English, therefore they have lack vocabulary and also teachers can't explore the other media to teaching English in the classroom.

\section{Carrying out the action research}

\section{a. Planning}

The authors make the simple lesson plan about specific topic, material, media, time, and schedule for observation. 


\section{DedikasiMU (Journal of Community Service)}

Volume 3, Nomor 1, Maret 2021

b. Implementing

In this part, the authors implement several activities written in the lesson plan

c. Observing

Observation have been implemented since the $7^{\text {th }}$ of February 2020 with classroom teacher on every Friday and Saturday in elementary school Dahanrejo Lor. Then proceed held on the $8^{\text {th }}$ of March 2020 every Sunday in village meeting hall with agenda 'English Fun Course'. Authors can give some suggestion during teaching learning process and also note the excesses use of guessing game to increase courage speaking skill children.

d. Reflecting

After executing the teaching process using games, the author review the occasion in classroom and in 'English Fun Course' as the reflection of the action. Authors evaluate process and result of the execution of games in English teaching. After that authors collect the data for used to determine the next step in the next cycle to reach goal which has been stated before.

The entire process of the action research implementation can be seen in Table 1

Table 1. Process of the action research

\begin{tabular}{|c|c|c|}
\hline Research steps & Aims & Notes \\
\hline \multirow[t]{3}{*}{ Pre Research } & $\begin{array}{l}\text { Identifying the problem } \\
\text { during teaching learning } \\
\text { process }\end{array}$ & $\begin{array}{l}\text { Observing teaching learning } \\
\text { process }\end{array}$ \\
\hline & $\begin{array}{l}\text { Identifying teacher's } \\
\text { technique and media to } \\
\text { teaching English in the } \\
\text { classroom }\end{array}$ & $\begin{array}{l}\text { Interviewing English teacher } \\
\text { and observing in the } \\
\text { classroom }\end{array}$ \\
\hline & $\begin{array}{l}\text { Identifying speaking skill of } \\
\text { the students }\end{array}$ & $\begin{array}{l}\text { Conducting pre-test overall } \\
\text { and one by one }\end{array}$ \\
\hline Research Implementation & $\begin{array}{l}\text { Conducting each cycle based } \\
\text { on the procedure of action } \\
\text { research, that is : planning, } \\
\text { implementing, observing, } \\
\text { reflecting, revising and } \\
\text { analyzing each procedure }\end{array}$ & $\begin{array}{l}\text { Implementing the action } \\
\text { plan in two cycles, each } \\
\text { cycle occur of two meeting: } \\
\text { Cycle } 1 \\
\text { Meeting } 1 \text { : teaching the } \\
\text { kind of fruits and family }\end{array}$ \\
\hline
\end{tabular}


DedikasiMU (Journal of Community Service)

Volume 3, Nomor 1, Maret 2021

\begin{tabular}{|c|c|c|}
\hline & phase & $\begin{array}{l}\text { members with share } \\
\text { information to each others } \\
\text { Meeting } 2 \text { : implementing } \\
\text { guessing games and } \\
\text { describing material from } \\
\text { meeting } 1 \\
\text { Cycle } 2 \\
\text { Meeting } 1 \text { : teaching } \\
\text { narrative text and telling } \\
\text { story to students } \\
\text { Meeting } 2 \text { : implementing } \\
\text { story games and guessing } \\
\text { games }\end{array}$ \\
\hline Post Research & $\begin{array}{l}\text { Identifying the opinion } \\
\text { students after implementing } \\
\text { guessing games }\end{array}$ & $\begin{array}{l}\text { Collecting daily record of } \\
\text { experiences from students } \\
\text { during learning English }\end{array}$ \\
\hline
\end{tabular}




\section{DedikasiMU (Journal of Community Service)}

Volume 3, Nomor 1, Maret 2021
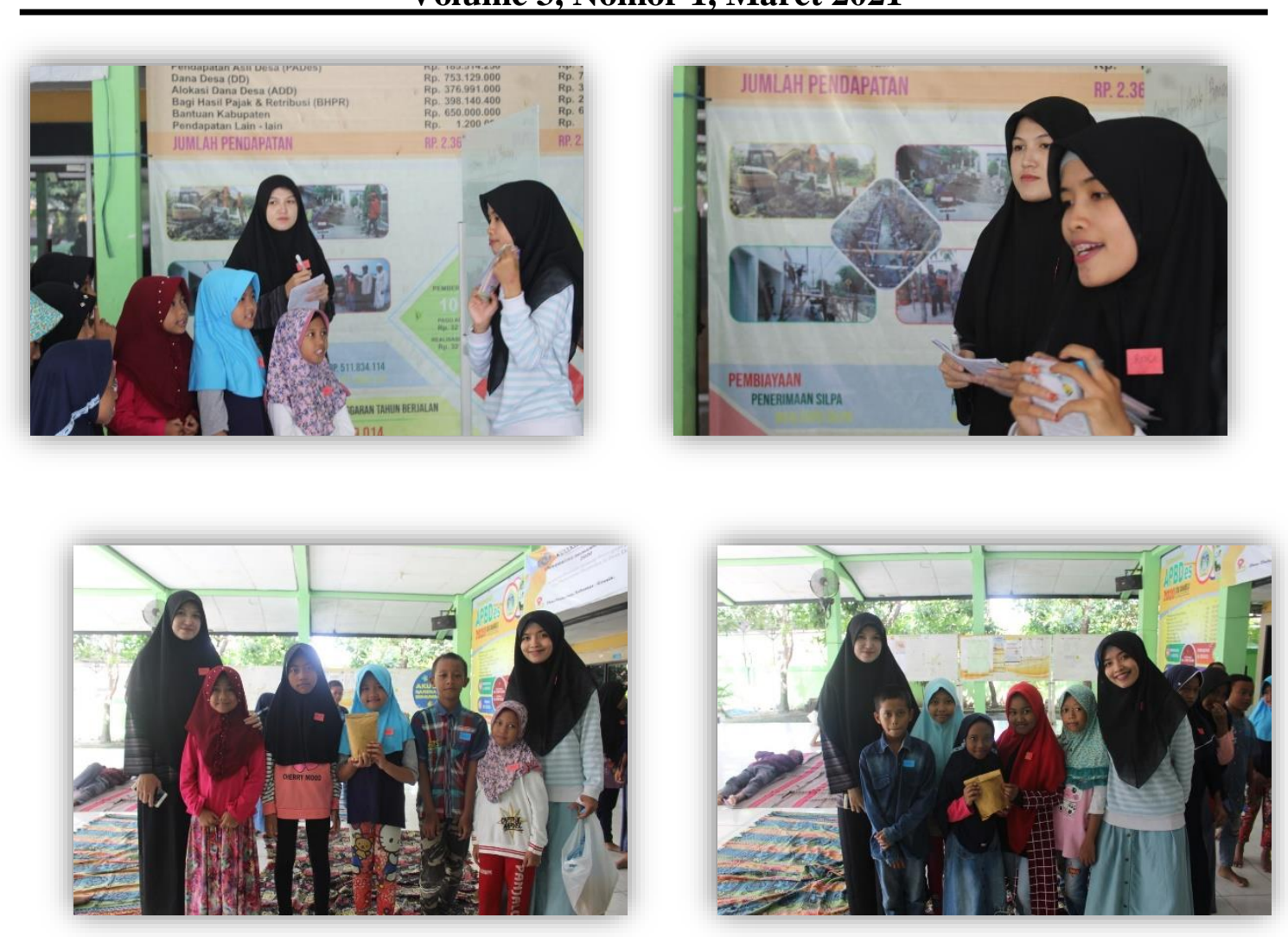

Figure 2. Learning and teaching activity in Dahanrejo village.

In this action research, there are standard to step the cycle. The cycle is stopped when of the of the students are able to carry out the accuracy criteria such as, correct in structural usage, correct in vocabulary usage and sign of fluency include a reasonably fast speed of speaking and only a small number of pauses and "ums" and "ers".

The grade of accuracy and fluency taken from criteria of assessment speaking test (Ur, 1996:135) as follows :

Table 2. Grade of accuracy and fluency

\begin{tabular}{|l|l|l|c|}
\hline \multicolumn{1}{|c|}{ Accuracy } & Score & \multicolumn{1}{|c|}{ Fluency } & Score \\
\hline ttle or no language produced & 1 & ttle or no communication & 1 \\
\hline $\begin{array}{l}\text { or vocabulary, mistake in basic } \\
\text { grammar, may have very strong } \\
\text { foreign accent }\end{array}$ & 2 & ery hesitant and brief utterances, & 2 \\
sometimes difficult to understand & & \\
$\begin{array}{l}\text { dequate but not rich vocabulary, } \\
\text { occasional grammar slips, slight } \\
\text { foreign accent }\end{array}$ & 3 & $\begin{array}{l}\text { ets ideas across, but hesitantly and } \\
\text { briefly }\end{array}$ & 3 \\
\hline
\end{tabular}




\section{DedikasiMU (Journal of Community Service)}

Volume 3, Nomor 1, Maret 2021

\begin{tabular}{|l|l|l|l|}
\hline $\begin{array}{l}\text { ood range of vocabulary, occasional } \\
\text { grammar slips, slight foreign accent }\end{array}$ & 4 & fective communication in short turns & 4 \\
\hline $\begin{array}{l}\text { ide vocabulary appropriately used, } \\
\text { virtually no grammar mistakes, native } \\
\text { like or slight foreign accent }\end{array}$ & 5 & asy and effective communication, uses & 5 \\
\hline
\end{tabular}

3. The application of learning media uses flashcard. The material used by authors aims to increase speaking skill and quality of learning that is more interesting and fun. Therefore, learning process with use game more innovative to increase knowledge and motivations students. The application of this media can make students and teachers interact ell so that students do not just sit down and also record English in the classroom, but also have media that can refresh the learning topic but not far from the topic of learning.

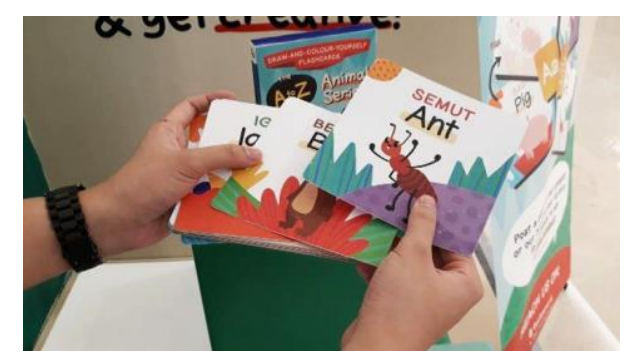

Figure 3. Flashcards for learning media

\section{Operational definition of variables}

-Instructional Media, media means an intermediary which in the link between the message source and the recipient of the message. Examples of some of these media can be used as teaching media if they can carry message in order to achieve learning goal. Thus, there must be a link between the media and the message and method (Indriana, 2011:13). Leslie J. Briggs (1979) states that teaching media are physical tools for delivering learning material in the form of books, films, video recording, so on. Briggs also argue that media is a tool to stimulate students to learn. 


\section{DedikasiMU (Journal of Community Service)}

Volume 3, Nomor 1, Maret 2021

-Flashcard is one of media to teaching vocabulary, as visual aids is an interesting media that can help the students memorize the words. Wright (1968:73) states that flashcard is printed card with words and picture which can be handled easily by the teacher.

-Vocabulary, it is essential for student who wants to master the language, so an understanding of good vocabulary is needed. For this reason, children who want to have a good vocabulary need to strengthen from the beginning of their vocabulary that is also conveyed by (Abbasian \& Ghorbanpour, 2016) Learning and teaching vocabulary has been considered as one of the most important mechanisms of any education program since the beginning. Vocabulary is a type of noun that means words used in language.

\section{RESULT AND DISCUSSION}

From the application of flashcards learning media that authors have conducted on $7^{\text {th }}$ of February 2020 and $8^{\text {th }}$ March 2020, to formal educators or instructions in Dahanrejo village authors get results of this action research during two cycle in Dahanrejo village used guessing game that students outcome can be increase their vocabulary and speaking skill.

The children who took part in this learning media socialization were very enthusiastic, because they were bored with monotonous learning media in the classroom, they only get drilling without raising awareness. This is the differences before and after treatment :

This is the value of the Dahanrejo children before English learning using guessing game

Table 3. Pretest result of children

\begin{tabular}{|c|c|c|}
\hline No & Name & Result \\
\hline 1. & Taufan & 40 \\
\hline 2. & Mustika & 50 \\
\hline 3. & Dina & 60 \\
\hline 4. & Andi & 45 \\
\hline
\end{tabular}




\section{DedikasiMU (Journal of Community Service)}

Volume 3, Nomor 1, Maret 2021

This is the value of the Dahanrejo children after English learning using guessing game

Table 4. Posttest result of children

\begin{tabular}{|c|c|c|}
\hline No & Name & Result \\
\hline 1. & Taufan & 75 \\
\hline 2. & Mustika & 90 \\
\hline 3. & Dina & 80 \\
\hline 4. & Andi & 87 \\
\hline
\end{tabular}

According to Nieven (2010), a media is said to be useful if the use of media can achieve the expected goals. The expected goal, in this case, is to increase students learning outcomes. Students learning outcomes include three aspects, namely knowledge, skills, and attitudes. Nevertheless, this study only focuses on the aspects of knowledge that are examined and the interest students in it. Based on Table 1, the results of the pretest conducted to students of Dahanrejo elementary school showed that the achievement of students learning outcomes was good enough before learning using guessing game. And after repeated learning using guessing games, the posttest results of students showed a good improvement almost for all children, as shown in table 2.

\section{CONCLUSION}

The primary purpose of this article is to increase courage children speaking skill and improve the quality of learning in English using guessing games and another media. The results of the action research given by the authors are the application of the media can improve the English language skills especially speaking of students and be able to provide variations in indoor learning that are not only fixed on the Package Books and Students Worksheets (LKS). Not only that, but the authors also found that the media was able to change the mood of students who did teaching through the media and were more interested in English. 


\section{DedikasiMU (Journal of Community Service)}

Volume 3, Nomor 1, Maret 2021

\section{REFERENCES}

Alqahtani, M. 2015. The Importance Of Vocabulary In Language. International Journal of Teaching and Education, 21-34.

Abbasian, G.-R., \& Ghorbanpour, E. (2016). The Effect of Flash Card-based Instruction on Vocabulary Learning by EFL Learners. International Journal Of Humanities And Cultural Studies, 1929-1938.

Buzanni. 2008. The Use of Guessing Games in Improving Students' Speaking Ability at the

Second Year Students Of MTS Ikhtiyarul Ummah Pamekasan. Malang: Institute of Teacher Training and Education Budi Utomo. [Online]. Available online at: http://historyofindonesi.blogspot.com/2013/07/the-use-of-guessing-games-inimproving.html Buzanni. 2008. [Accesed on September 4, 2013]

Dwiyanti. 2009. The Improvement Students’ Speaking Skill Through Guessing Games

Technique. Jakarta: English Departement School of Teacher Training and Education Kusuma Negara. [Online]. Available online at: http://www.scribd.com/doc/22057958/THEIMPROVEMENT-OF- STUDENT\%E2\%80\%99S-SPEAKING-SKILL-THROUGHGUESSING-GAMES-TECHNIQUE). [Accesed on September 4, 2013]

Chen, I-Jung. 2005. Using Games to Promote Communicative Skills in Language Learning. The Internet TESL Journal, XI (2), 1-4

Hadi, Abdul. 2011. Abdul Hadi Bab 1.2.3. [Online]. Available online at: http://www.scribd.com/doc/63364739/Abdul-Hadi-Bab-1-2-3 . [Accesed on September 4th, 2013]

Hopkins, David. 1992. A Teacher's Guide to Classroom Action Research. Great Buckingham: Open University Press.

Indiana, Dina. 2011 Variety of aids Teaching Media.Yogyakarta: DIVA Press.

Kemmis, Stephen, Mc. Taggart Robbin. 1990. The Action Research Planner. Australia: Deakin University.

Wright. 1968. Teaching by Using Flashcard. London: Edward Arnold Publisher Ltd. 